\title{
Refugee debate and networked framing in the hybrid media environment
}

\section{Pöyhtäri, Reeta}

2021-02-01

Pöyhtäri , R , Nelimarkka , M , Nikunen , K , Ojala , M , Pantti , M \& Pääkkönen , J 2021 , '

Refugee debate and networked framing in the hybrid media environment ' , International

pÿCommunication Gazette , vol. 83 , no. 1 , 1748048519883520 , pp. 81102 . https://doi.org/10.1177/174804851988

http://hdl.handle.net/10138/326178

https://doi.org/10.1177/1748048519883520

unspecified

acceptedVersion

Downloaded from Helda, University of Helsinki institutional repository.

This is an electronic reprint of the original article.

This reprint may differ from the original in pagination and typographic detail.

Please cite the original version. 


\title{
Refugee debate and networked framing in the hybrid media environment
}

\author{
Reeta Pöyhtäri, Tampere University, Finland \\ Matti Nelimarkka, University of Helsinki and Aalto University, Finland \\ Kaarina Nikunen, Tampere University, Finland \\ Markus Ojala, University of Helsinki, Finland \\ Mervi Pantti, University of Helsinki, Finland \\ Juho Pääkkönen, University of Helsinki and Aalto University, Finland
}

\section{Abstract}

In this article, we analyse how the debate on the 'refugee crisis' has been constructed in Finnish news media and social media by using big data analytics. The study applies big data with the aim of exploring the dynamics between the mainstream news media and social media and the ways in which these dynamics shape and strategically amplify different understandings of the refugee crisis. The research highlights over-emphasis of crime and threat-oriented themes on refugee issues in social media, as well as illuminates the distinct role of social media platforms in shaping debates through user practices of hyperlink sharing and networked framing. Together these findings suggest that the hybrid media environment provides a possible arena for polarization of the refugee debate that could also be used for political ends.

\section{Keywords}

'refugee crisis', news media, social media, big data analytics, topic modeling, hyperlink analysis, networked framing, polarization 


\section{Introduction}

In 2015, over 32,000 people applied for asylum in Finland, a nearly tenfold increase on the 3,490 applications received in 2014. Although lower than in some other European countries, this number was the fourth largest amongst EU member states in 2015 in proportion to overall population of the receiving country (Eurostat, 2016). The arrival of asylum seekers to Western Europe has been framed as a 'crisis' and has produced conflicting and contradictory discourses. Nationalist and racist discourses have been countered by liberal-humanitarian discourses underscoring 'our' obligation to help those in distress (Harrison, 2016; Holmes and Castañeda, 2016). The 'refugee crisis' has thus amplified tensions among citizens, political parties and EU member states, fuelling xenophobic political movements as well as anti-racist protests and calls for greater hospitality (Chouliaraki and Georgiou, 2017).

Several studies show that the news on the 'refugee crisis' has been poorly contextualized, framing the crisis in terms of managing the emergency and threat (e.g. Berry et al., 2015). However, previous research has largely focused on legacy media, and relatively little attention has been paid to the articulations of the 'refugee crisis' in citizen debates across various online platforms (see, however, for previous research e.g. Siapera et al., 2018). Moreover, there has so far been little research on how the dynamics between mainstream news media and social media discussions have affected the public debate on refugees.

This research sets out to address this lack by using big data analytical techniques to analyse the topics and hyperlink sharing in both news media and social media. Our starting point is that today's 'hybrid media system' (Chadwick, 2013), which is characterized by a complex interdependence between old and new media logics, significantly shapes the structure and dynamics of the present refugee debate. In the hybrid media environment, traditional media 
organisations and new media actors are involved in a dynamic interplay in which news content provides the first input to online debates, further shaping subsequent media coverage (Guggenheim et al., 2015; Zhou and Moy, 2007), especially through practices of networked framing (Meraz and Papacharissi, 2013; Papacharissi, 2015: 60-61).

\section{Networked framing in a hybrid media environment}

The traditional news media remain a powerful actor in the contemporary media environment, constructing major events such as the 'refugee crisis' as public issues through their reporting. News-making involves journalists, their news organisations, and their sources in a process of framing which shapes how covered events become represented in news stories (Entman, 1993). Due to the privileged position of government officials and politicians as news sources; administrative and economic concerns, as well as political contests, tend to be favoured perspectives for reporting news events (de Vreese, 2005; Reinemann et al., 2012). This is also the case with refugee and asylum issues, where criminality, security threats, and economic strain tend to feature as dominant frames in reporting (Greussing and Boomgaarden, 2017).

However, the news media's power to determine how major events are publicly interpreted may have significantly weakened or has at least changed due to the rise of social media, blogs, and alternative online media. In the contemporary 'hybrid' media environment (Chadwick, 2013), networked actors on these various online platforms regularly appropriate news content, sharing it to their followers while adding comments and views to express their personal values and interests (Bennett and Segerberg, 2012; Meraz, 2011). Networked publics can thus significantly shape the ways in which news topics are discussed. The notion of 'networked framing' refers to online activities through which new views and values are introduced by non-elite actors to shape how 
public events turn into a popular story (Meraz and Papacharissi, 2013; Papacharissi, 2015: 60-61)

- these activities differ from traditional news reporting.

On one hand, these activities concern the commenting of news stories and the events they report on in the comments sections of online news platforms or on Facebook, Twitter, and other platforms. On the other hand, networked framing is about giving more prominence to given news stories, views, or interpretations through activities such as linking, liking, sharing, and retweeting. Resulting from these practices of networked framing diverging interpretations of issues and events develop, transform, gain salience, and occasionally clash with each other. In other words, networked framing illustrates how 'culturally -resonant' stories among particular groups and users spread and gain visibility on social media (Jenkins et al., 2013).

As networked framing involves multiple civil society groups and is not constrained by professional news values and discursive tropes, more plurality is potentially added to the available frames and discourses (Fenton, 2016: 34-36). This could be particularly relevant for the refugee debate, where the news media has been found to provide lopsided and negative coverage that omits the voices of refugees (e.g. Berry et al., 2015; Greussing and Boomgaarden, 2017).

The increased diversification of public interpretations enabled by social media, however, may not necessarily reflect any democratic ideals of a public sphere. Instead of the kind of plurality of opinions and interpretive frames advocated by liberal theorists, networked framing may lead to greater political polarization whereby participants are divided into antagonistic camps.

However, academic research is undetermined if and how social media use contributes to political polarization (among others, Adamic and Glance, 2005; Bakshy et al. 2015; Fletcher and Nielsen, 2018). Polarization phenomena have been identified in some online communities though network analysis (e.g. Adamic and Glance, 2005; Jacobson et al., 2016). This means that actors link 
to sites that support their chosen frames and discourses, leading to a highly partisan discussion at the expense of a greater variety of perspectives.

The divergence of frames and interpretations, together with selective use of other sites, can contribute towards selective exposure, whereby content consumers read news stories from only a particular perspective (e.g. Fletcher and Nielsen, 2018; Morgan et al., 2013).

Furthermore, the networked framing, occurring through hyperlinks or link sharing in communities, informs recommendation engines about relationships between different perspectives. This way, the recommendation engines may lead to reinforcement of these filter bubbles as their recommended content is based on particular frames (e.g. Möller et al., 2018; Pariser, 2011).

Building on the theories of hybrid media environment and networked framing, this paper adopts data science approaches to study the similarities, differences, and interconnections between news media and social media debates on refugees in Finland during the crisis. First, through topic modeling, we assess how the issue of refugees has been framed in news media coverage and social media discussions. Second, we examine how the news media and social media debates are intertwined through linking practices, in particular, how news content is strategically appropriated by users to shape citizen debates on various online platforms. Accordingly, we present the following research questions:

RQ1 What are the topics and themes that frame the refugee issue on the mainstream news outlets and social media?

RQ2 How does hyperlink sharing contribute to the framing of the 'refugee crisis' and how does it vary across mainstream media and various social media platforms?

RQ3 How do framing and hyperlink sharing contribute to diversification or polarization of the refugee debate? 


\section{Data and Methods}

The study builds on data drawn from Finnish news media, social media, and online discussion forum platforms between 1 March 2015 and 31 December 2016, during the most intensive period of the 'refugee crisis'i. It allows us to explore how these themes are discussed and what kind of tactics are used to reinforce xenophobic frames. Our dataset consists of 27,504 online news articles from national media (YLE, Helsingin Sanomat, Iltalehti, and Kauppalehti) and regional media (Lännen media, Aamulehti, Kainuun Sanomat, Lapin Kansa, Pohjolan Sanomat, Satakunnan Kansa, and Keskisuomalainen) $)^{\mathrm{ii}}$, and in total $1,082,815$ unique messages from a variety of social media platforms, including Twitter, Facebook, Instagram and YouTube, as well as hundreds of Finnish online discussion forums and thousands of blogs provided by Futusome ${ }^{\mathrm{iii}}$. The data were collected using six keywords pertaining to immigration and refugees: the standard language words for 'immigrant' ('maahanmuuttaja'), 'refugee' ('pakolainen'), and 'asylum seeker' ('turvapaikanhakija'). Besides neutral words, we decided to include also words commonly used in social media discussions intruder' ('maahantunkeutuja') and abbreviations of 'immigrant' ('mamu') and 'intruder' ('matu'). Excluding these non-neutral words would have resulted in a biased sample. The sample would not have included social media discussions in Finland that are known to be negative about immigration or even racist, already long before the 2015 'refugee crisis' (see e.g. Mäkinen, 2016; Nikunen, 2015; Ylä-Anttila, 2017). ${ }^{\text {iv }}$

\section{Framings of the refugee discussion}

We utilized topic modeling or latent Dirichlet allocation (LDA; Blei, 2012) to explore topics and themes of the refugee debate (RQ1). Due to the quantity of source data, instead of content analysis or grounded theory method, we opted to apply an unsupervised machine learning approach, which automatically extracts groupings of words in documents (news articles and social 
media messages) which often appear together ${ }^{v}$. Topic modeling is an output of two relationships: the first between words and topics and the second between documents and topics. The strength of the relationship is measured through posterior values, ranging from 0 (weak) to 1 (strong). As is usual in the topic modeling process, we pre-processed documents to remove 'stopwords'vi and common and rare words.

The topic modeling algorithms require researchers to choose the number of topics they want the machine learning methods to produce. Debate continues with regard to how to choose the right number of topics (e.g. Chang et al., 2009). Some have argued that the number of topics is best chosen through the highest interpretability of topics (e.g. Levy and Franklin, 2013). In this study, we opted to utilize the harmonic log-likelihood criteria (Wallach et al., 2009). This is a statistical approach to choosing the number of topics. It reduces some of the biases potentially inherent in the interpretation-driven selection of the number of topics, where the researcher's own ideas of 'right' topics may play a part in the analysis process. This statistical analysis approach produced 100 topics for the social media data and 91 for news data. For further analysis, topics are given an interpretation and labelled. We initially used the 20 highest-ranked words that showed the highest accuracy in the labelling process (Aletras et al., 2017). During this stage we excluded topics which were hard to interpret per usual approach. For example, some topics were removed due to their arbitrariness. Others did not have enough inner coherence, and some were left out because of lack of relevance to our RQs.

Our final analysis was based on topics with the highest relevance to the refugee debate or broader discussion about immigration, 58 for the social media data and 38 for the news media data. A second labelling was based on the selection of 20 random text examples from 200 documents with the highest posterior values to increase validity (Grimmer and Stewart, 2013). After this stage, we grouped related topics together thematically. This thematic grouping enabled 
us to compare the topics belonging under each theme in social media and news media (these will be specified later in Table 2). Furthermore, the themes reveal the discursive contexts that surround the refugee issue.

However, how do these topics correspond to these theory-driven concepts, such as discursive context? As Jacobi and colleagues (2016) and Maier et al. (2018) state, topics do not represent any theoretical concept by themselves. In previous research, topics have been used to analyse themes, frames, issues, or voices (e.g. Jacobi et al., 2016). Thus, substantive interpretability is crucial with topic modelling. Here we used topic modeling to identify themes (cf. DiMaggio et al., 2013; Ylä-Anttila, 2018) of the refugee debate. The grouped topics constitute these themes of the debate, consisting of several topics. These themes, together with the contents of the topics (the words and text examples) illustrate the discursive context and the frames that were used in the discussion.

\section{Use of hyperlinks in the refugee discussion}

While the text analysis helps us understand what topics and themes are prominent, it does not provide information about the relationship the texts have with other mediums (RQ2). However, networked framing always exists in a larger media ecology. To address this gap, mixed-method approaches can be used to understand both the content and structure of online media (Maier et al., 2018; Nelimarkka et al., 2018).

To understand the relationship between the refugee discussion and the wider media ecology, we extracted hyperlinks in online discussions, and analysed from which pages (origins) links were shared to other sites (targets). This approach is often used to study polarization of online communities (Jacobson et al., 2016) or to understand the relationship between actors (Maier et al., 2018). 


\section{Results}

\section{Topic analysis}

As shown in Table 1, news media and social media shared ten themes. Furthermore, news media contained unique topics related to international politics that did not appear in social media discussions. Similarly, social media discussions contained topics that were not covered in the news, including Finland's war history with nationalistic connotations (see below).

Table 1. Thematic categories based on the topic modeling of the discussions in news media and social media.

\begin{tabular}{|l|}
\hline Thematic categories in news media and social media \\
\hline 1. Crime \\
\hline 2. Societal debate and activism \\
\hline 3. Asylum processes and policies \\
\hline 4. Reception centres and asylum seekers \\
\hline 5. Integration and cultural differences \\
\hline 6. Refugee crisis in Europe \\
\hline 7. International causes of the refugee crisis \\
\hline 8. Immigration in Europe \\
\hline 9. Political parties and immigration politics \\
\hline 10. Social politics and policies \\
\hline 11. International relations (in news media only) \\
\hline 12. Nationalism (in social media only) \\
\hline
\end{tabular}

Three conclusions can be drawn from thematical analysis. First, while the thematic categories were largely shared by both news media and social media, the number of topics in 
these categories was higher for social media (all the topics and their numbers in social media and in news are listed in Table 2 below). Evidently, the debate on social media was more versatile in terms of topics addressed. This is not a surprising finding, as networked publics have unlimited possibilities to open new discussion threads and lead the discussion into new directions (Meraz and Papacharissi, 2013; Papacharissi, 2015) and thus in larger volume than news media. In contrast, mainstream news frames selected early on in reporting tend to dominate throughout a news event, leading to less diversity to the debate (Greussing \& Boomgaarden, 2017).

Table 2. Themes and topics of social media and news media contents (bolding highlights the differences between social media and news media topics).

\begin{tabular}{|c|c|c|}
\hline $\begin{array}{l}\text { Theme / Number of topics in } \\
\text { social media / in news }\end{array}$ & Social media topics (58) & News media topics (38) \\
\hline 1. Crime (5/4) & $\begin{array}{l}\text { \#1 Police reporting of violent crime } \\
\text { \#52 Violent crimes } \\
\text { \#27 Immigrant rape statistics } \\
\text { \#50 Sexual assaults } \\
\text { (\#85 Islam (and terrorism)) }\end{array}$ & $\begin{array}{l}\text { \#1 Human trafficking } \\
\text { \#7 Terror attacks in Europe } \\
\text { \#21 Asylum seekers and } \\
\text { police/security } \\
\text { \#22 Crimes, criminal process }\end{array}$ \\
\hline $\begin{array}{l}\text { 2. Societal debate and activism } \\
(12 / 6)\end{array}$ & $\begin{array}{l}\text { \#2 Anti-immigration movements } \\
\text { \#40 Social media discussions \& hate speech } \\
\text { \#59 Societal atmosphere } \\
\text { \#60 Immigration debate/extremes/poles } \\
\text { \#69 Immigration debate/extremes/sense } \\
\text { \#53 Propaganda (by mainstream media) } \\
\text { \#68 Propaganda (against Helsingin } \\
\text { Sanomat, pro MV - fake news site) } \\
\text { \#75 Insults towards immigrants } \\
\text { \#82 Stereotypical beliefs about immigrants } \\
\text { \#94 Abusive/racist expressions about } \\
\text { immigrants } \\
\text { \#56 Humanity (wrong/right) } \\
\text { \#99 Startup refugees - initiative }\end{array}$ & $\begin{array}{l}\text { \#10 Social media discussions } \\
\# 36 \text { Anti-immigration movements } \\
\text { \#61 \#81 Racism 1-2 } \\
\text { \#69 Immigration debate } \\
\text { \#90 European values }\end{array}$ \\
\hline
\end{tabular}




\begin{tabular}{|c|c|c|}
\hline $\begin{array}{l}\text { 3. Asylum processes and policies } \\
\text { (7/3) }\end{array}$ & $\begin{array}{l}\text { \#8 Refugee policies (immigration control) } \\
\text { \#11 Asylum-seeking process } \\
\text { \#43 Receiving refugees } \\
\text { \#55 Refugee flood \& Ministry of Interior } \\
\text { \#63 Border control/legality } \\
\text { \#71 Treatment of refugees } \\
\text { \#32 Human rights legislation }\end{array}$ & $\begin{array}{l}\text { \#56 Minor asylum seekers } \\
\text { \#62 Asylum-seeking process } \\
\text { (Migri) } \\
\text { \#89 Border control }\end{array}$ \\
\hline $\begin{array}{l}\text { 4. Reception centres and asylum } \\
\text { seekers }(7 / 3)\end{array}$ & $\begin{array}{l}\text { \#24 Reception centres } \\
\text { \#20 Attacks on reception centres (KKK) } \\
\text { \#81 Arson (of reception centres)/lucrative } \\
\text { business } \\
\text { \#9 Asylum seekers using services } \\
\text { \#73 Housing of asylum seekers on } \\
\text { countryside } \\
\text { \#87 Asylum seekers in swimming halls } \\
\text { \#98 Aid/voluntary work }\end{array}$ & $\begin{array}{l}\text { \#8 Establishing reception centres } \\
\text { \#75 Reception centres } \\
\text { \#34 Aid/voluntary work }\end{array}$ \\
\hline $\begin{array}{l}\text { 5. Integration and cultural } \\
\text { differences }(5 / 2)\end{array}$ & $\begin{array}{l}\text { \#10 Financial support for integration } \\
\text { \# } 15 \text { Integration services } \\
\text { \#17 Integration } \\
\text { \#85 Islam } \\
\text { \#93 Relationships (child/Muslim marriages) }\end{array}$ & $\begin{array}{l}\text { \#32 Reception and integration of } \\
\text { immigrants in municipalities } \\
\text { \#64 Islam }\end{array}$ \\
\hline 6. Refugee crisis in Europe (4/8) & $\begin{array}{l}\text { \#12 EU asylum policies/burden-sharing } \\
\text { system } \\
\text { \#16 German asylum politics } \\
\text { \#46 Balkan route } \\
\text { \#72 Mediterranean route }\end{array}$ & $\begin{array}{l}\text { \#4 German asylum politics } \\
\text { \#13 EU burden-sharing system } \\
\text { \#27 Nordic asylum politics } \\
\text { \#79 EU-Turkey agreement } \\
\text { \#80 Swedish politics } \\
\text { \#6 Balkan route } \\
\text { \#11 Calais } \\
\text { \#29 Mediterranean route }\end{array}$ \\
\hline $\begin{array}{l}\text { 7. International causes of the } \\
\text { refugee crisis }(3 / 3)\end{array}$ & $\begin{array}{l}\text { \#5 Population growth (in the world) } \\
\text { \#70 Refugee camps } \\
\text { \#74 Conflict (in Middle East) }\end{array}$ & $\begin{array}{l}\text { \#23 International crisis aid } \\
\text { \#24 Asylum seeking outside } \\
\text { Europe } \\
\text { \#87 Conflict (in Syria/Middle East) }\end{array}$ \\
\hline 8. Immigration in Europe (2/1) & $\begin{array}{l}\text { \#13 Suburbs in Nordic cities } \\
\text { \#96 Brexit }\end{array}$ & \#78 Brexit \\
\hline $\begin{array}{l}\text { 9. Political parties (governmental) } \\
\text { and immigration politics }(4 / 2)\end{array}$ & $\begin{array}{l}\text { \#42 Centre Party } \\
\text { \#44 National Coalition party } \\
\text { \#65 Finns Party } \\
\text { \#76 Government/immigration politics }\end{array}$ & $\begin{array}{l}\text { \#57 Political parties and } \\
\text { immigration } \\
\text { \#65 Finns Party }\end{array}$ \\
\hline
\end{tabular}




\begin{tabular}{|c|c|c|}
\hline 10. Social politics and policies $(7 / 5)$ & $\begin{array}{l}\text { \#33 Bogus migrants } \\
\text { \#62 Costs for asylum seekers } \\
\text { \#67 Health care (contagious diseases) } \\
\text { \#79 Social security } \\
\text { \#83 Labour force } \\
\text { \#89 Labour migration (control) } \\
\text { \#95 Housing }\end{array}$ & $\begin{array}{l}\text { \#30 Migration research } \\
\text { \#91 Municipality politics } \\
\text { \#20 Health care } \\
\text { \#39 Housing benefits } \\
\text { \#14 Employment }\end{array}$ \\
\hline $\begin{array}{l}\text { 11. International relations (in news } \\
\text { media only) }(0 / 1)\end{array}$ & & $\begin{array}{l}\# 86 \text { (Finland-)Russia relationship } \\
\text { and politics }\end{array}$ \\
\hline $\begin{array}{l}\text { 12. Nationalism (in social media } \\
\text { only) }(3 / 0)\end{array}$ & $\begin{array}{l}\text { \#57 Fatherland/war } \\
\text { \#100 Fatherland/veterans } \\
\text { \#88 Nationalities }\end{array}$ & \\
\hline
\end{tabular}

Second, our analysis shows that news media and social media had slightly diverging geographical focuses (see Table 2, themes from 1 to 6 ). The debate on social media had an apparent national orientation, focusing on the local consequences of the arrival of asylum seekers. The news media covered the refugee issue from more international perspective and placed the emphasis on European refugee policies. When news media adopted a domestic perspective, the focus of the coverage was predominantly on asylum administration and policies.

Third, social media debates differed from the news coverage in the prevalence of overtly negative, anti-immigrant framings characterized by uncivil arguments, hostile expressions and circulation of negative news and stereotypes. Issues discussed in the news also often had a negative connotation, e.g. through discussing problems or challenges associated with the 'refugee crisis'. However, social media discussions were not nounded by journalistic norms related to professional distance and neutrality. For example, Crime (purportedly committed by asylum seekers and other immigrants) was a prevalent theme in both news coverage and social media (see Table 2, theme 1). The news media focused on the criminal process, human trafficking, and terrorism, whereas social media debates addressed a wider range of topics, typically with an anti- 
immigration stance, such as the increase in the number of sexual assaults and other crimes committed by asylum seekers.

Therefore, it was evident that the same themes were framed differently in our two media. To illustrate these differences, we examined the most commonly used words belonging to the crime theme (see Table 3 below). The news topic 'Crime and criminal process', for instance, contained mainly neutral words such as 'suspect', 'crime', 'police', 'case', 'convict', 'victim', 'sentence', and 'deed'. On social media, related topics typically contained more inflammatory and affective words. For instance, the 'Violent crime' topic was made up of words that all described serious criminal acts: 'assault', 'beat', 'murder', 'attack', 'robbery', 'rob', 'killing', 'indictment', 'abuse', and 'group rape'. The vignettes clearly showed how crime topics were discussed on social media platforms in a sensational manner, combined with an emotional anti-immigration judgement, as well as repeatedly giving visibility to old cases, while the news media based its reporting on current official statistics and police information.

Table 3. Selected topics belonging to the crime theme, their top words and vignettes in social media and news media.

\begin{tabular}{|c|c|}
\hline \multicolumn{2}{|c|}{ CRIME THEME, SELECTED SOCIAL MEDIA TOPICS AND RELATED WORDS } \\
\hline Sexual assaults (\#50) & Violent crime (\#52) \\
\hline $\begin{array}{l}\text { harassment, harass, abuse, Köln, sex crime, } \\
\text { new year, crime, offense report, click, } \\
\text { abuser }\end{array}$ & $\begin{array}{l}\text { assault (noun), assault (verb), beat, murder, attack, robbery, rob, } \\
\text { killing, indictment, abuse }\end{array}$ \\
\hline $\begin{array}{l}\text { Vignette } \\
\text { '... revealed! Police: Asylum seekers harassed } \\
\text { children in Helsinki - "Young girls are being } \\
\text { attacked"! }>\text { HS Friday 8.1.2016 Asylum } \\
\text { seekers harassing children and women are a } \\
\text { serious problem in Helsinki, police says. -----' } \\
{[\ldots]}\end{array}$ & $\begin{array}{l}\text { Vignette } \\
\text { "Here some examples of "single cases", a common nominator to } \\
\text { them is that the perpetrators have been immigrants, or people } \\
\text { with immigrant background. Evenly guilty to the crimes on this list } \\
\text { are the tolerant politicians and -parties, churnalists/leftist media, } \\
\text { green-leftist rottened administrators and the NGOs getting their } \\
\text { income from asylum tourism. And, as unfortunate as it is, this is } \\
\text { only the beginning. [...] }\end{array}$ \\
\hline \multicolumn{2}{|c|}{ CRIME THEME, SELECTED NEWS TOPICS AND RELATED WORDS } \\
\hline Human trafficking (\#1) & Crime and criminal process (\#22) \\
\hline $\begin{array}{l}\text { victim, report, violence, human trafficking, } \\
\text { amnesty, prisoner, girl, prison, Nigeria, } \\
\text { organization }\end{array}$ & $\begin{array}{l}\text { suspect, crime, police, case, sentence (verb), victim, sentence } \\
\text { (noun), act, court, prosecute }\end{array}$ \\
\hline $\begin{array}{l}\text { Vignette } \\
\text { ‘Over } 5600 \text { Nigerian women and girls arrived }\end{array}$ & $\begin{array}{l}\text { Vignette } \\
\text { 'STT, Helsinki. In Laukaa in Central Finland three people died on }\end{array}$ \\
\hline
\end{tabular}


in Italy by sea last year. The amount increased from the year before, as in 2014 1200 women arrived. According to the International Organization for Migration IOM, four out of five were sold for prostitution. [...]
Sunday in a pizzeria as victims of homicide. According to police, a man was caught nearby the scene as a suspect. - Both the victims and the suspect have a foreign background and they have been living in Finland for long, told the inspector Markku Latvala. He could not yet tell, whether any of them is a Finnish citizen. Latvala stresses that although a person has been caught, at this point he is only a suspect. [...]'

Similarly, in reporting on asylum policy and processes (Table 2, theme 3 ), the news media concentrated on administrative processes and border control, and the two topics mostly contained words related to officials and legal terminology. In contrast, social media discussions contained a broader variety of topics, including government actions and immigration policies. Many of these topics contained allusions to a refugee 'flood', 'illegal' migrants, and 'lax' asylum policies, indicating that anti-immigrant views again strongly shaped these debates.

The discussion on societal debate and activism that evolved around the 'refugee crisis' (Table 2, theme 2) showed also this pattern. In the news media, these issues were handled with reference to anti-immigration movements, heated social media discussions, and immigration debate, as well as discussions of racism. On social media, the topics within the theme were again more numerous and emphasized polarized views of the social debate with both anti- and prorefugee perspectives. Some topics revealed racist and insulting language used on social media with regard to both asylum seekers and people who are deemed 'too tolerant', as well as antipathy towards legacy news media, which is often believed to be biased, to produce promigration propaganda, and to hide information from citizens. This highlights the conflict-seeking character of the social media debates concerning the refugee issue. While the social media discussions and news media content both focused on negative issues, on social media the intensity and the number of topic threads with negative connotations were both much higher than in news.

It would be, however, too simplistic to claim that social media debates were only negatively coloured. As the social media platforms differ from one another and allow multiple 
actors to participate, we also found topics that brought up humanitarian viewpoints, such as

human rights legislation, pro-refugee initiatives, and the assistance that is needed in receiving the asylum seekers. These topics were, however, in the minority, not only in social media discussions but also in the news content.

\section{Hyperlink analysis}

The thematic similarity between social media content and news content is also supported by our findings using hyperlink analysis. The analysis of most linked domains (see Table 4 below) shows that discussions on the 'refugee crisis' concentrated on news content both in social media and in the news media. The most-linked domains were traditional news media websites followed by some of the popular social media and user-generated content services (e.g. YouTube, Facebook, Twitter). The public service news domain YLE was the most frequently shared overall, which is not surprising due to YLE's major role in the Finnish media system and as it offers a wide range of free news content, both nationally and locally.

Table 4. Most-linked domains in social media and news media.

\begin{tabular}{|c|c|c|c|}
\hline \multicolumn{2}{|c|}{ Most-linked domains in social media } & \multicolumn{2}{|c|}{ Most-linked domains in the news media } \\
\hline Domain & Count & Domain & Count \\
\hline $\begin{array}{l}\text { yle.fi } \\
\text { (public broadcaster's news } \\
\text { site) }\end{array}$ & $36,055(5.0 \%)$ & $\begin{array}{l}\text { yle.fi } \\
\text { (public broadcaster's news } \\
\text { site) }\end{array}$ & 3,965 (42.3\%) \\
\hline youtube.com & $15,829(2.2 \%)$ & wikipedia.org & $158(1.7 \%)$ \\
\hline twitter.com & $15,271(2.2 \%)$ & facebook.com & $145(1.6 \%)$ \\
\hline $\begin{array}{l}\text { iltalehti.fi } \\
\text { (tabloid news site) }\end{array}$ & $13,542(1.9 \%)$ & twitter.com & $118(1.3 \%)$ \\
\hline $\begin{array}{l}\text { mvlehti.net } \\
\text { (counter media site) }\end{array}$ & $13,139(1.8 \%)$ & $\begin{array}{l}\text { hs.fi } \\
\text { (news site) }\end{array}$ & $114(1.2 \%)$ \\
\hline $\begin{array}{l}\text { hs.fi } \\
\text { (news site) }\end{array}$ & $11,624(1.6 \%)$ & youtube.com & $104(1.1 \%)$ \\
\hline $\begin{array}{l}\text { iltasanomat.fi } \\
\text { (tabloid news site) }\end{array}$ & $10,246(1.4 \%)$ & $\begin{array}{l}\text { lannenmedia.fi } \\
\text { (regional news site) }\end{array}$ & $75(0.8 \%)$ \\
\hline $\begin{array}{l}\text { mtv.fi } \\
\text { (TV news site) }\end{array}$ & $8052(1.1 \%)$ & $\begin{array}{l}\text { theguardian.com } \\
\text { (UK news site) }\end{array}$ & $62(0.7 \%)$ \\
\hline $\begin{array}{l}\text { blogspot.fi } \\
\text { (blogging platform) }\end{array}$ & $7037(1.0 \%)$ & $\begin{array}{l}\text { svt.se } \\
\text { (Swedish public } \\
\text { broadcasters' news site) }\end{array}$ & $61(0.7 \%)$ \\
\hline
\end{tabular}




\begin{tabular}{|l|l|l|l|}
\hline $\begin{array}{l}\text { uusisuomi.fi } \\
\text { (online news site) }\end{array}$ & $5018(0.7 \%)$ & $\begin{array}{l}\text { migri.fi } \\
\text { (Finnish Immigration } \\
\text { Service) }\end{array}$ & $59(0.6 \%)$ \\
\hline fb.me & $4211(0.6 \%)$ & $\begin{array}{l}\text { aamulehti.fi } \\
\text { (Regional news site) }\end{array}$ & $56(0.6 \%)$ \\
\hline $\begin{array}{l}\text { suomi24.fi } \\
\text { (discussion forum) }\end{array}$ & $3825(0.5 \%)$ & $\begin{array}{l}\text { dn.se } \\
\text { (Swedish news site) }\end{array}$ & $56(0.6 \%)$ \\
\hline facebook.com & $3696(0.5 \%)$ & $\begin{array}{l}\text { aftonbladet.se } \\
\text { (Swedish tabloid news site) }\end{array}$ & $51(0.5 \%)$ \\
\hline $\begin{array}{l}\text { verkkouutiset.fi } \\
\text { (political news site) }\end{array}$ & $3011(0.4 \%)$ & bbc.com & $45(0.5 \%)$ \\
\hline wikipedia.org & $2801(0.4 \%)$ & $\begin{array}{l}\text { europa.eu } \\
\text { (website of the EU) }\end{array}$ & $44(0.5 \%)$ \\
\hline
\end{tabular}

We observed that use of links demonstrated networked framing on different social media platforms. Actors on different platforms appropriated and reframed news content according to their personal, political, and commercial interests (Bennett and Segerberg, 2012). Varied news media links were most actively shared on social media discussion forums (demonstrating specific personal and political interests), while the news media showed a tendency to link primarily to their own domain (supporting their commercial interests). We could also see that within social media, popular counter media sites, known for their anti-immigration or even openly racist contents, were popular sources of information (mvlehti.net, as well as certain blogs in blogspot.fi). These domain links were not shared at all by the news media.

To analyse the differences between social media platforms, we studied the contents of the most popular direct links on the five most active platforms in the refugee debate: Suomi24, Twitter, Facebook, Vauva.fi, and Hommaforum. The linking patterns on these platforms showed notable differences (see Table 5 below), suggesting that each of the platforms had particular sources they used in the discussion, again indicating the framing values that the users of that platform found central (Meraz and Papacharissi, 2013; Nelimarkka et al., 2018). 
Table 5. The most-shared direct links on various social media platforms (excluding links to general news domains).

\begin{tabular}{|c|c|c|}
\hline $\begin{array}{l}\text { Social media } \\
\text { platform }\end{array}$ & Link and content & Shares \\
\hline \multirow{3}{*}{$\begin{array}{l}\text { keskustelu.suomi } \\
24 . f i \\
\text { (commercial, general } \\
\text { discussion forum } \\
\text { with various sub- } \\
\text { forums on various } \\
\text { topics) }\end{array}$} & $\begin{array}{l}\text { vaalit.perussuomalaiset.fi/ } \\
\text { Elections website of the Finns-party }\end{array}$ & 335 \\
\hline & $\begin{array}{l}\text { halla-aho.com/scripta/eu_maahanmuutto_taakanjako.html } \\
\text { A blog post of the Finns (present) party leader, MEP Jussi Halla-aho (known for anti- } \\
\text { immigration sentiments) on refugees in the Mediterranean and burden-sharing within EU, } \\
\text { 16.1.2014 }\end{array}$ & 213 \\
\hline & $\begin{array}{l}\text { facebook.com/jussi.hallaaho/posts/748071178646412 } \\
\text { Post by Halla-aho on burden-sharing within EU, 26.3.2015 }\end{array}$ & 194 \\
\hline \multirow{2}{*}{$\begin{array}{l}\text { Links to content } \\
\text { created by Finns } \\
\text { Party and its } \\
\text { members (known } \\
\text { for anti- } \\
\text { immigration } \\
\text { populism) }\end{array}$} & $\begin{array}{l}\text { yle.fi/uutiset/eva_maahanmuutto_kaksinkertaistettava/7767100 } \\
\text { Yle news on need to double migration due to lack of labour force, 29.1.2015 }\end{array}$ & 193 \\
\hline & $\begin{array}{l}\text { iltalehti.fi/pakolaiskriisi/2015112020695298_cm.shtml } \\
\text { Tabloid news on reception centres as 'business', 20.11.2015 }\end{array}$ & 183 \\
\hline \multirow{5}{*}{$\begin{array}{l}\text { Twitter } \\
\text { Links to positive } \\
\text { news on and } \\
\text { about asylum } \\
\text { seekers and } \\
\text { immigration }\end{array}$} & $\begin{array}{l}\text { yle.fi/uutiset/8613502 and yle.fi/uutiset/leskirouva_linnea_palkkasi_irakilaisen_ } \\
\text { turvapaikanhakijan_ostin_alille_halal- } \\
\text { lihaa_ja_toppapoksyt_han_karraa_minua_mieheni_haudalle/8613502 } \\
\text { Yle news: Elderly lady Linnea hired asylum-seeker Ali from Iraq as her assistant, 24.1.2016 }\end{array}$ & 224 \\
\hline & $\begin{array}{l}\text { yle.fi/uutiset/8433231 and yle.fi/uutiset/supercell- } \\
\text { miehilta_miljoonalahjoitus_maahanmuuttajanuorille/8433231 } \\
\text { Yle news: Owners of Supercell company donate millions for immigrant youth, 5.11.2015 }\end{array}$ & 219 \\
\hline & $\begin{array}{l}\text { yle.fi/uutiset/sipila_annan_kotini_turvapaikanhakijalle/8282743 and } \\
\text { yle.fi/uutiset/8282743 } \\
\text { Yle news: Prime minister Sipilä promises to give his house at the disposal of asylum- } \\
\text { seekers, 5.9.2015 }\end{array}$ & 191 \\
\hline & $\begin{array}{l}\text { yle.fi/uutiset/8757220 } \\
\text { Yle news: Asylum seekers are rather highly educated, 21.3.2016 }\end{array}$ & 110 \\
\hline & $\begin{array}{l}\text { lapinkansa.fi/kotimaa/tiesitko-nama-tosiseikat-pakolaisista (broken link 16.10.2019) } \\
\text { Regional news site: Did you know these facts about refugees, 7.9.2015 }\end{array}$ & 98 \\
\hline $\begin{array}{l}\text { Facebook } \\
\text { (containing public } \\
\text { Facebook pages) }\end{array}$ & $\begin{array}{l}\text { yle.fi/uutiset/tony_blair_pyytaa_anteeksi_irakin_sodan_erehdyksia/8406806 } \\
\text { Yle news: Tony Blair apologizes for mistakes made in Iraq war (e.g. leading to birth of } \\
\text { ISIS), 25.10.2015 }\end{array}$ & 37 \\
\hline \multirow{4}{*}{$\begin{array}{l}\text { Links to news on } \\
\text { background and } \\
\text { causes of the } \\
\text { Middle-East and } \\
\text { Syrian crisis }\end{array}$} & $\begin{array}{l}\text { hs.fi/ulkomaat/a1446264957007 } \\
\text { Helsingin Sanomat article on USA former Minister of Foreign Affairs Condoleezza Rice, } \\
\text { 1.11.2015 }\end{array}$ & 37 \\
\hline & $\begin{array}{l}\text { news.bbc.co.uk/2/hi/americas/2711623.stm } \\
\text { News on coalition of USA and UK, George W. Bush and Tony Blair, 31.3.2003 }\end{array}$ & 33 \\
\hline & $\begin{array}{l}\text { taloussanomat.fi/kolumnit/2010/07/23/irakin-oljysta-vaietaan-yha/201010174/145 } \\
\text { Column on how UK entered Iraq war on a false basis (e.g. exaggeration of terrorist threat; } \\
\text { importance of oil), 23.7.2010 }\end{array}$ & 32 \\
\hline & $\begin{array}{l}\text { yle.fi/uutiset/totta_vai_tarua_yle_selvitti_turvapaikanhakijoihin_liittyvien_vaittamien_to } \\
\text { denperaisyyden/8251658 } \\
\text { Yle news: True or false? Finding the truth about the stereotypes concerning asylum } \\
\text { seekers (mostly proved false), 26.8.2015. }\end{array}$ & 28 \\
\hline \multirow{2}{*}{$\begin{array}{l}\text { Vauva.fi } \\
\text { (commercial } \\
\text { discussion forum } \\
\text { with various topics, } \\
\text { mainly concentrating }\end{array}$} & $\begin{array}{l}\text { kansalaisaloite.fi/fi/aloite/970 } \\
\text { Petition on deportation of criminals with foreign nationality, } 5.11 .2014\end{array}$ & 177 \\
\hline & $\begin{array}{l}\text { optula.om.fi/material/attachments/optula/julkaisut/tutkimuksia- } \\
\text { sarja/xz5bk8f2h/265_lehti_ym_2014.pdf (protected link) } \\
\text { Research publication of Ministry of Justice, 'Immigrants as perpetrators and victims of } \\
\text { crimes' }\end{array}$ & 36 \\
\hline
\end{tabular}




\begin{tabular}{|c|c|c|}
\hline \multirow{4}{*}{$\begin{array}{l}\text { on family issues and } \\
\text { relationships) } \\
\text { Links to news on } \\
\text { immigrant crime } \\
\text { and related issues }\end{array}$} & $\begin{array}{l}\text { polisen.se/global/www\%20och\%20intrapolis/\%c3\%96vriga\%20rapporter (broken link } \\
16.10 .2019) \\
\text { Report by the Swedish Police }\end{array}$ & 31 \\
\hline & $\begin{array}{l}\text { adressit.com/kansanaanestys_maahantunkeutujien_poistamisesta__broken link } \\
\text { 16.10.2019) } \\
\text { Petition on deportation of 'intruders' }\end{array}$ & 29 \\
\hline & $\begin{array}{l}\text { hs.fi/ulkomaat/a1458635856051?ref=hs-etusivu-luetuimmat-\#2 } \\
\text { Helsingin Sanomat news on Brussels terror attacks: ISIS has a hundred suicide bombers } \\
\text { within Europe ready to attack, 22.3.2013 }\end{array}$ & 22 \\
\hline & $\begin{array}{l}\text { hs.fi/kotimaa/a1448950672350 } \\
\text { Helsingin Sanomat news: has the unsafety of women grown? Nine questions about rape } \\
\text { crimes in Finland, } 2.12 .2015\end{array}$ & 22 \\
\hline \multirow{6}{*}{$\begin{array}{l}\text { Hommaforum.org } \\
\text { (non-commercial } \\
\text { discussion forum that } \\
\text { concentrates on anti- } \\
\text { immigration } \\
\text { discussion) }\end{array}$} & $\begin{array}{l}\text { asfalttikukka.blogspot.fi/ } \\
\text { A blog of a private person, who writes on societal topics. Based on the posts, the writer } \\
\text { has been active in Finns party and the Close Borders movement during the 'refugee crisis' }\end{array}$ & 1059 \\
\hline & $\begin{array}{l}\text { youtu.be/j9e_vcsut0a } \\
\text { Video no longer available }\end{array}$ & 176 \\
\hline & $\begin{array}{l}\text { paavotajukangas.com (broken link } 16.10 .2019) \\
\text { A counter news site, information on immigrant crime, problems with immigration in } \\
\text { Finland and abroad, link to hate radio channel Vihapuhe.fm (Hate speech fm). Contents } \\
\text { produced in collaboration with e.g. Hommaforum }\end{array}$ & 146 \\
\hline & $\begin{array}{l}\text { friatider.se } \\
\text { A Swedish news site, news on e.g. politics, immigrant crime, etc. }\end{array}$ & 146 \\
\hline & $\begin{array}{l}\text { avpixlat.info } \\
\text { A Swedish counter media site; news on immigrant crime, problems with immigrants and } \\
\text { immigration, especially with Muslims and Islam }\end{array}$ & 145 \\
\hline & $\begin{array}{l}\text { rahmispossu.net } \\
\text { No longer existing Facebook page, concentrating on counter news against the 'misleading } \\
\text { mainstream media' }\end{array}$ & 145 \\
\hline
\end{tabular}

On Suomi24, the most-shared links lead to content created by the Finns party or its key members (known to hold anti-immigration views), as well as to sensational tabloid news stories (asylum seekers as a 'lucrative' business; suspected abuses by politicians). Negative, (suspected) immigrant-crime related content was also shared on Vauva.fi. On Hommaforum the links clearly situated the forum as a part of a wider international network of populist, anti-immigration counter media websites: the links shared led to similar websites in Finland and abroad, as well as to blogs sharing a like-minded worldview (see also Ylä-Anttila, 2018). Compared to the discussion forums, the links shared on Twitter and Facebook appeared quite different. On Twitter, the shared news offered a predominantly positive view on the refugee issue, highlighting examples of cooperation between asylum seekers, immigrants, and Finns. On Facebook, the most shared news articles 
examined the reasons behind the crisis in the Middle East, relating it to matters of international politics in the 1990s.

Our analysis shows that news content was widely shared on these social platforms, but it was used to serve different purposes in them. On Facebook and Twitter, news stories were shared to provide critical and contextualising information, as well as to promote positive views on the refugee issue, whereas the observed discussion forums used the news and news-like content to spread negative views. The link contents and link-sharing practices, especially on Suomi24 and Hommaforum, suggest that the user practices on these platforms was motivated by antiimmigration party politics or ideologies: the tendency to share content related to Finns party politics and anti-immigration counter media sites was evident. The platform affordances thus allowed or supported the user practices of networked framing, including biased link sharing.

\section{Conclusion and discussion}

Meraz and Papacharissi's (2013) account of the Twitter communications during the Arab spring indicates how the affordances of social media can help networked activists to counter official narratives of events. For these authors, the notion of networked framing seems to carry the promise of increasing diversity, plurality, and participation in public debate. However, as Tufekci (2014) points out, social media platforms are also used by actors to attack others, thus contributing to increasingly polarized information environments. In recent years, the use of digital networks by various conservative, anti-immigrant, and right-wing groups has made it evident that social media can be turned into a tool for limiting the freedoms and rights of others. There is thus nothing inherently democratizing or pluralizing about networked framing as a citizen activity. What we see here is a much more contested use of framing. 
As seen in the hyperlink analysis, news media sources dominated the debates on social media. However, in this case of refugee debate, they were actively and strategically circulated to strengthen particular viewpoints, enabled by the structures and technologies of the hybrid media environment. The utilization of sources to support different framings can explain the observed versatility of topics in social media discussions in comparison to news content, where there were fewer topics contained within each theme. Partly, this can be contributed to the differences of volume; e.g., there is much more social media discussion on a topic, thus allowing more perspectives to emerge. Furthermore, this analysis showed how networked framing is used to support political interests: the social media platforms hosted by anti-immigrant agents used links to spread their views and contents effectively within their own community. In addition, the ability to create separate communities on social media, for example through hosting online forums or sub-communities within larger social media platforms, demonstrates how online polarization builds in these communities - it emerges due to actors' networked framing of the stories towards particular purposes. Therefore, we see an overemphasis on themes of crime, threat, and fear connected to refugee issues on particular social media platforms.

What is noteworthy, and the subject of further research, is the ways in which, on controversial themes such as crime and rape, the primary definers of the debate emerge from the realm of alternative and counter media. This also highlights the specificity of different social media platforms that seems to engender, through affordances and cultures of participation, different kinds of attitudes, tones, and understandings towards the refugee debate. These different platform affordances can be used to further separate or complicate the debate. The second area for further investigation is integration of the networked framing literature with studies of hybrid media and online polarization studies. Through this conceptual work, we can reflect social media features, such as lack of gatekeepers and different motivations of networked framing, and their 
implications in the hybrid media environment for polarization. This may help scholars studying the hybrid media environment and polarization to shift the focus from descriptive studies of the media ecology to examinations of individual actors creating these phenomena.

Our analysis shows that the practices of networked framing and biased linking behaviour were effective in shaping the refugee debate in Finland. By observing and comparing the content in both news media and social media with the help of data science, we have been able to demonstrate how the hybrid media system in this particular case created space for polarization of the refugee debate. This was particularly enforced by an active group of anti-immigrant users who were politically motivated. The case therefore shows more generally, how politically motivated groups can make use of the hybrid media environment, also for other, more productive ends. These results speak about the benefits of triangulation of both content analysis and link pattern analysis to understand how networked framing functions within hybrid media systems. Furthermore, they show the importance of qualitative steps for understanding the contexts in which the topics emerge.

\section{References}

Adamic, LA and Glance, N (2005) The political blogosphere and the 2004 U.S. election: divided they blog. In: Proceedings of the 3rd international workshop on Link discovery, 36-43.

Aletras N, Baldwin T, Lau JH and Stevenson M (2017) Evaluating topic representations for exploring document collections. Journal of the Association for Information Science and Technology 68(1): 154-167.

Bakshy E, Messing S and Adamic LA (2015) Exposure to ideologically diverse news and opinion on Facebook. Science 348, 6239 6(2015), 1130- 1132. https://doi.org/10.1126/science.aaa1160 arXiv:gr-qc/9809069v1

Bennett, WL and Segerberg A (2012) The logic of connective action. Information, Communication \& Society 15(5): 739-768.

Berry M, Garcia-Blanco I and Moore K (2015) Press coverage of the refugee and migrant crisis in the EU: A content analysis of five European countries. Report for the UNHCR. Available at: http://www.unhcr.org/protection/operations/56bb369c9/press-coverage-refugee-migrantcrisiseu-content-analysis-five-european.html.

Blei, DM (2012) Probabilistic topic models. Communications of the ACM 55(4): 77-84. 
Chadwick, A (2013) The Hybrid Media System: Politics and Power. Oxford: Oxford University Press. Chang J, Gerrish S, Wang C and Blei DM (2009) Reading tea leaves: How humans interpret topic models. In: Bengio Y, Schuurmans D, Lafferty JD, Williams CKI and Culotta A (eds) Advances in Neural Information Processing Systems 22. New York: Curran Associates: 288-296.

Chouliaraki L and Georgiou M (2017) Hospitability: The communicative architecture of humanitarian securitization at Europe's borders. Journal of Communication 62(2): 159-180. De Vreese C H (2005) News framing: Theory and typology. Information Design Journal + Document Design 13(1): 51-62.

DiMaggio P, Nag M and Blei D (2013) Exploiting affinities between topic modeling and the sociological perspective on culture: Application to newspaper coverage of U.S. government arts funding. Poetics 41(6): 570-606.

Entman R (1993) Framing: Towards clarification of a fractured paradigm. Journal of Communication 43(4): 51-58.

Eurostat (2016) Record number of over 1.2 million first time asylum seekers registered in 2015. Eurostat News Release, 4 March 2016. Available at:

https://ec.europa.eu/eurostat/web/products-press-releases/-/3-04032016-AP (accessed 12 October 2019).

Fenton N (2016) Digital, Political, Radical. Cambridge, UK: Polity.

Fletcher R and Nielsen RK (2018) Are people incidentally exposed to news on social media? A comparative analysis. New Media \& Society 20(7): 2450-2468.

Ghosh R and Asur S (2013) Mining information from heterogeneous sources. A topic modeling approach. In: Yang Q \& Menczer, F. (eds), Proceedings of Mining Data Semantics in Heterogeneous Information Networks Workshop at the 19th ACM SIGKDD. Chicago, USA. 10.8.2013-14.8.2013. Greussing E and Boomgaarden HG (2017) Shifting the refugee narrative? An automated frame analysis of Europe's 2015 refugee crisis. Journal of Ethnic and Migration Studies 43(11): 17491774.

Grimmer J and Stewart BM (2013) Text as data: The promise and pitfalls of automatic content analysis methods for political texts. Political Analysis 21(3): 267-297.

Guggenheim L, Jang SM, Bae SY and Neuman WR (2015) The dynamics of issue frame competition in traditional and social media. The Annals of the American Academy of Political and Social Science 659(1): 207-224.

Harrison AC (2016) Mediations of 'the refugee crisis': The (ir)reconciliation of ideological contradictions in Fortress Europe. Networking Knowledge 9(4): 1-16. Available at:

http://ojs.meccsa.org.uk/index.php/netknow/article/view/449/271.

Holmes SM and Castañeda H (2016) Representing the 'European refugee crisis' in Germany and beyond: Deservingness and difference, life and death. American Ethnologist 43(1): 12-24. Jacobi C, van Atteveldt W and Welbers K (2016) Quantitative analysis of large amounts of journalistic texts using topic modeling. Digital Journalism 4(1): 89-106.

Jacobson S, Myung E and Johnson SL (2016) Open media or echo chamber: The use of links in audience discussions on the Facebook pages of partisan news organizations. Information, Communication \& Society 19(7): 875-891.

Jenkins H, Ford S and Green J (2013) Spreadable Media. New York: NYU Press.

Levy KEC and Franklin M (2013) Driving regulation: Using topic models to examine political contention in the U.S. trucking industry. Social Science Computer Review 32(2): 182-194.

Maier D, Waldherr A, Miltner P, Jähnichen P and Pfetsch B (2018) Exploring issues in a networked public sphere. Social Science Computer Review 36(1): 3-20. 
Meraz S (2011) The fight for 'how to think': Traditional media, social networks, and issue interpretation. Journalism 12(1): 107-127.

Meraz S and Papacharissi Z (2013) Networked gatekeeping and networked framing on \#Egypt. The International Journal of Press/Politics 18(2): 138-166.

Morgan JS, Lampe C and Zubair Shafiq M (2013) Is news sharing on Twitter ideologically biased?

In: Proceedings of the 2013 conference on computer supported cooperative work - CSCW'13. New York: ACM Press: 887.

Mäkinen K (2016) Uneasy laughter: encountering R the anti-immigration debate. Qualitative Research 16(5) 541-556.

Möller J, Trilling D, Helberger, N and van Es B (2018) Do not blame it on the algorithm: An empirical assessment of multiple recommender systems and their impact on content diversity. Information, Communication \& Society 21(7): 959-977.

Nelimarkka M, Laaksonen S-M and Semaan B (2018) Social media is polarized, social media is polarized. In: Proceedings of the 2018 on designing interactive systems conference 2018 - DIS ' 18. New York: ACM Press: 957-970.

Nikunen K (2015) Politics of irony as the emerging sensibility of the anti-immigrant debate. In: Andreassen R and Vitus K (eds) Affectivity and Race: Studies from Nordic Contexts. London: Routledge, pp. 21-42.

Papacharissi Z (2015) Affective Publics: Sentiment, Technology and Politics. Oxford, UK: Oxford University Press.

Pariser E (2011) The filter bubble: What the Internet is hiding from you. Penguin UK.

Reinemann C, Stanyer J, Scherr S and Legnante G (2012) Hard and soft news: A review of concepts, operationalizations and key findings. Journalism 13(2): 221-239.

Siapera E, Boudourides M, Lenis S, et al. (2018) Refugees and network publics on Twitter:

Networked framing, affect, and capture. Social Media + Society, January-March 2018: 1-21.

Tufekci Z (2014) Social movements and governments in the digital age: Evaluating a complex landscape. Journal of International Affairs 68(1): 1-19.

Wallach HM, Murray I, Salakhutdinov R and Mimno D (2009) Evaluation methods for topic models. In: Proceedings of the 26th annual international conference on machine learning - ICML '09. New York: ACM Press: 1-8.

Ylä-Anttila T (2018) Populist knowledge: 'Post-truth' repertoires of contesting epistemic authorities. European Journal of Cultural and Political Sociology. Epub ahead of print 24 May 2017. doi:10.1080/23254823.2017.1414620.

Zhou Y and Moy P (2007) Parsing framing processes: The interplay between online public opinion and media coverage. Journal of Communication 57(1): 79-98.

\section{Funding}

This research is funded by Helsingin Sanomat Foundation, and Academy of Finland, $\mathrm{n}: \mathrm{o}$ 295948/2016. Authors also thank Yleisradio, Sanoma Corporation and Alma Media for their support in data collection from Finnish mediums. 


\section{Notes}

${ }^{i}$ In this intensive period, Finland received the most asylum applications. Also, the public debate in both news and social media was the most active measured in amounts of news and posts.

ii More specifically, the news data of $\mathrm{N}=27,504$ contained 15,089 news from local and from 12,415 national outlets. We were not able to discuss the differences between local and national media, however, this could be subject of future research.

iii Futusome is a Finnish social media data company that provides the most comprehensive access to publicly available Finnish social media and online discussion forum data. They collect their data using a combination of APIs and web scraping, depending on the service/source of data. This approach limits our analysis in various ways. Most importantly, we do not capture private discussions in private online communities where stronger language may be used. In political and sensitive topics, private communities may be used to large degree. Our scoping captures rather "public sphere", online content openly accessible to e.g., search engines, and thus, which can influence our general perception. More specifically, the social media data of 1,082,815 messages in this case study consisted of the following: 596,938 forum posts; 140,716 Twitter tweets; 90,551 Twitter retweets (Futusome uses the Twitter streaming API collection and follows a constantly, automatically updated set of Finnish language tweeters); 80,951 Facebook comments (from public groups); 15,266 Facebook links; 5,379 Facebook photos; 4,502 Facebook status updates; 1,060 Facebook videos; 178 Facebook posts; 17 Facebook events; 105,679 news comments; 15,745 blog posts; 13,707 blog comments; 3,471 blog answers; 3,182 Youtube video comments; 330 Youtube videos; 2,286 Googleplus posts; 270 Googleplus post comments; 1,155 Instagram image comments; 1,411 Instagram images; 21 Pinterest pins.

iv The abbreviation 'mamu' has been used in social media discussions also in insulting ways already since 2001 at least; 'matu' is a new word that was actively introduced in social media as an alternative to 'mamu' during the 2015 'refugee crisis' and has gained prominence since - leaving out this word would thus have given a false idea of the 2015-2016 refugee debate. All the six words were used in social media debates in 2015-2016, 'refugee' ('pakolainen') and 'immigrant' ('maahanmuuttaja') being the most commonly used words, 'mamu' and 'matu' were used about half as often as the most common words, and 'asylum seeker' ('turvapaikanhakija') and 'intruder' ('maahantunkeutuja') were the rarest. The usage of different words was verified by consulting the Finnish language bank, and its online data repository of social media data concerning Finland's largest public discussion forum Suomi24 from 2001 to 2016, https://www.kielipankki.fi and data corpus https://korp.csc.fi. In our dataset, we found the following amount of hits for various keywords in the Futusome data: 'pakolai': 491,220, 'turvapaikanhak': 293,655; 'maahanmuutta': 258,066, 'mamu': 248,737, 'matu': 140,257, 'maahantunkeutuj': 15,951; and in the news: 'pakolai': 32,645, 'turvapaikanhak': 25,252, 'maahanmuutta': 10,852, 'mamu': 208, 'matu': 104, and 'maahantunkeutuj': 36.

${ }^{\vee}$ The latter dataset, social media data, is heterogeneous, that is, versatile in length. To provide an overview of this dataset, we computed the topics from all of them through the same process. However, topic model may provide suboptimal solutions in these cases (e.g., Ghosh \& Asur, 2013). Future research could explore in detail differences in social media channels.

vi We pre-processed documents to remove 'stopwords' and frequent and infrequent words before conducting the machine learning. Frequent and infrequent words are removed as they do not add value in the analysis. For example, word 'and' may be common in the dataset, but it does not add value in the interpretation of discussions. Similarly, 'stopwords' refer to common words, which provide no value for interpretation, such as the keywords based on which the data was collected. 